\title{
SEASONAL MIGRATION AND LAND-USE CHANGE IN GHANA
}

\author{
A. K. BRAIMOH* \\ Centre for Development Research, University of Bonn, Walter Flex Strasse 3, 53113 Bonn, Germany \\ Received 8 March 2003; Revised 5 September 2003; Accepted 12 September 2003
}

\begin{abstract}
When farmers migrate yearly to a village to carry out intense farming during the rainy season, and thereafter return to a more permanent place of abode this is referred to as seasonal migration. The impact of such migration on land-use/land-cover change in an area within the Volta Basin of Ghana was examined using satellite image analysis and socioeconomic surveys. The most drastic land-cover change involved the conversion of woodland to agricultural land, while there was also a general transition to less vegetation cover. Socioeconomic surveys revealed that most of the migration occurred during the post-structural adjustment period in Ghana with declining soil fertility accounting for the highest per cent of causes of migration. Multiple regression results highlighted the role of population size and distribution, marketing of agricultural produce and technological evolution of the household in determining agricultural land-use change. Policy initiatives that could lead to environment conservation are suggested. Copyright (C) 2004 John Wiley \& Sons, Ltd.
\end{abstract}

KEY WORDS: seasonal migration; land-use change; agricultural intensification; macroeconomic policies

\section{INTRODUCTION}

The Volta River watershed in West Africa drains about $400000 \mathrm{~km}^{2}$ and comprises parts of Ghana, Burkina Faso, Togo, Benin, Mali and Cote d'Ivoire (Figure 1). There is a high incidence of poverty in the largely rural area, with a population growth rate of about 3 per cent. The main source of livelihood is rain-fed agriculture, but there is wide variability in precipitation (Andreini et al., 2000). The low rainfall reliability and the problem of water insecurity (Asante et al., 2002) therefore reinforce migration as an alternative livelihood strategy in the Volta Basin part of Ghana (Overseas Development Institute, 1999).

Migration patterns in the Volta Basin can also be explained by the strategic importance of Tamale as an administrative and commercial centre. Abudulai (1996) reports that Tamale District's population witnessed a phenomenal increase of about 136 per cent from 98560 in 1984 to 232243 inhabitants in 1995. Thus, there was pressure on available land in municipal and peri-urban Tamale, leading to the displacement of many farmers and conversion of farmlands to residential uses. Besides, most farmland has been over-cropped due to reduction in fallow period length, resulting in a decline in soil fertility. This led many farmers to migrate into previously uncultivated areas.

Another factor that has made population movements rampant in the Volta Basin is the macroeconomic reforms in Ghana over the last few years. Four macroeconomic epochs in Ghana can be identified since independence:

1. Between 1957 and 1982, the government of Ghana consistently intervened in both input and output markets of the agricultural sector. Stiff restrictions were imposed on food imports to encourage domestic production. For instance, the overvaluation of Ghanaian currency contributed to an increase in protection of the rice sector between the mid-1970s and early 1980s (Abdulai and Huffman, 2000).

\footnotetext{
${ }^{*}$ Correspondence to: A. K. Braimoh, Centre for Development Research, University of Bonn, Walter Flex Strasse 3, D-53113 Bonn, Germany. E-mail: abraimoh@uni-bonn.de
} 


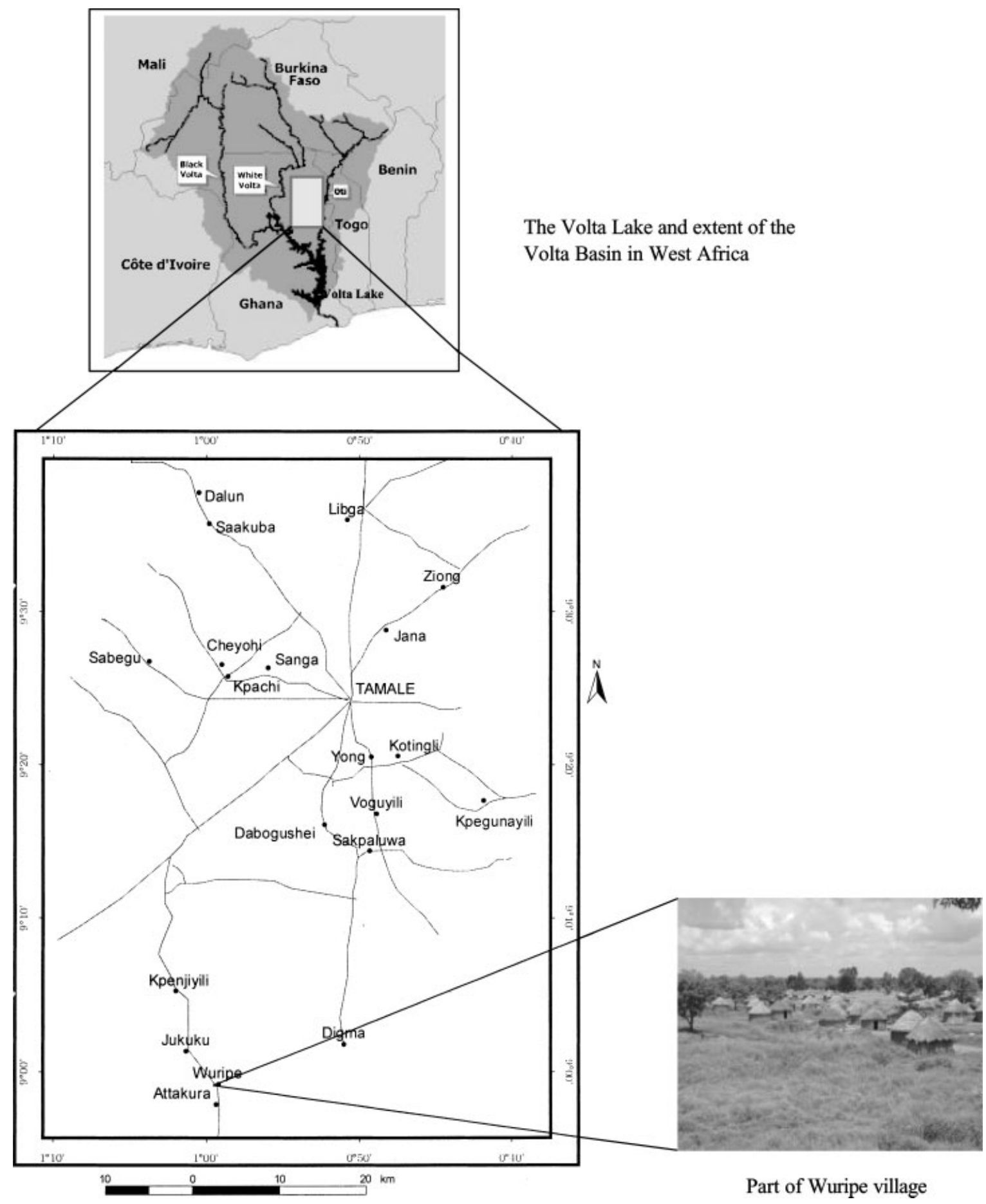

Figure 1 . The study area. 
2. In the Stabilization/Economic Recovery Programme Phase I (1983-1986), protection of the food sector decreased substantially as a result of changes in the fiscal environment. The currency was progressively devalued in nominal terms from 2.75 to 90 Ghanaian cedis per US dollar (Tshikata, 1999).

3. In the structural adjustment/Economic Recovery Programme Phase II (1987-1991), liberalization of food trade and import of fertilizers and other agricultural inputs continued. Removal of subsidies on fertilizers and other inputs substantially increased the prices of these inputs to farmers due to devaluation of exchange rates. While trade liberalization exposed the food sector to stiff competition with imported food items, currency devaluation made imported food relatively more expensive than domestic food, giving domestic agricultural producers a competitive edge (Abdulai and Huffman, 2000). By the end of the economic recovery programmes, inflation had reduced from 142 per cent in 1983 to 10 per cent in 1991.

4. The post-structural adjustment period (1992 to present) has been characterized by recurrent fiscal imbalances. The period has witnessed large wage increases in the public sector and overspending on capital budgets, particularly roads. The government also pursued initiatives to enhance the efficiency of the tax system.

The response of the agricultural sector to these policy changes has received attention in the literature (e.g. Abdulai and Hazell, 1995). Pearce (1992) and Horton et al. (1994) indicate that there was substantial migration of labour back into agriculture in Ghana during the structural adjustment period. This is because structural adjustment policies led to a reduction of the gap between rural and urban wages (Ahmed and Lipton, 1997), making urban wages less attractive than before structural adjustment. Furthermore, empirical analyses by Abdulai and Huffman (2000) show that farmers in Northern Ghana are highly responsive to changes in product and input markets associated with structural adjustment. This suggests that structural adjustment policies have made profit maximisation an appealing economic objective for farmers.

The objective of this study is to quantifying changes in land-use as a result of migration to Wuripe in Northern Ghana. Wuripe was established about fifteen years ago. Four households settled temporarily in the village in the year 1989, but by 2001, a total of 201 households consisting of 1361 individuals had migrated into the village. One striking feature of Wuripe is that the inhabitants do not live there all the year round. They are migrants from neighbouring towns and villages (Tamale, Damongo, Yendi and their environs) within the Northern Region of Ghana. Every year, they come to Wuripe at the onset of the farming season (typically June), and carry out intense farming and other natural resource-based activities, until the beginning of the dry season when lack of water for domestic and other uses forces them back to their permanent places of abode. This phenomenon is euphemistically referred to as seasonal migration. The study focuses on the farming community and their impact on land-cover in the environment. The major hypothesis tested is that changing economic opportunities in the economic recovery programmes and post-structural adjustment periods affected migration patterns, and subsequently the amount of land that migrant households cleared for food and commercial crops. Changes in land-cover are quantified and driving forces of land-use change analysed. Policy implications will be highlighted.

\section{LAND-COVER CLASSIFICATION AND ANALYSIS}

Three Landsat TM scenes of the study area acquired over a period of 15 years (that is 5 November 1984, 21 December 1992 and 7 November 1999) were used. Each image was georectified to UTM coordinates (Zone 30) using ground control points collected during field studies between August and October 2001. A first-order affine transformation was applied to all data, resulting in a root mean square error below $15 \mathrm{~m}$ for each image. Landcover classification for the images was carried out based on field knowledge, available topographic maps and insitu observations. The procedure first involved radiometric rectification of the 1984 and 1992 images to the 1999 image (Hall et al., 1991), followed by a tasselled cap orthogonal transformation of the original six bands in each image into three new dimensional space, corresponding to soil brightness, green vegetation and moisture indices respectively. Apart from yielding relevant input (training data) for land-cover classification, the transformation also improved visual discrimination of land-cover types. Classification was carried out on the three bands of the tasselled cap transformation using the maximum likelihood algorithm. The classification scheme in Table I was used to assign pixels to land-cover classes. 
Table I. Land-cover classification scheme

\begin{tabular}{ll}
\hline Land-cover class & Description \\
\hline Closed woodland & Mainly trees over $3 \mathrm{~m}$ high, riparian vegetation $(\geq 150$ trees/ha) \\
Open woodland & Open woodland with undergrowth of shrubs and grasses $(75-150$ trees $/$ ha $)$ \\
Grassland & Complex mixture of grasses and shrubs without or with scattered trees $(<10$ trees/ha) \\
Settlement & Built up area, roads and bare surfaces \\
Water bodies & Inland waters, reservoirs \\
Cultivated land & New farmland, harvested agricultural land \\
\hline
\end{tabular}

First, changes in land-cover were determined by computing the difference in land-cover statistics (proportions) over two time periods (Table II). Second, overall change from one land-cover type to another (1984-1999) was determined by pixel-to-pixel comparison resulting in a land-cover change matrix in which each element is the proportion of total land area of its class in 1984 that changed to the other class in 1999. Thus, the main diagonal elements in Table III are land-cover proportions that did not experience a change in land-cover between 1984 and 1999.

The land-cover maps for Wuripe area are presented in Figure 2. The overall classification accuracies of the maps were 85 percent, 82 percent and 88 percent respectively for 1984, 1992 and 1999. Land-cover statistics are presented in Figure 3. Closed woodland decreased from over 50 per cent of total land area in 1984 to 18 per cent in 1999. Grassland also decreased but less than the closed woodland. Open woodland increased from 17 per cent of total land area in 1984 to 40 per cent in 1999.

Changes in land-cover are presented in Table II. The table reveals profound change in land-cover classes except the amount of land covered by water. In the first period (1984-1992) corresponding to the stabilization and structural adjustment eras, closed woodland and grassland experienced a decrease of 24 per cent and 14 percent

Table II. Land-cover change statistics ${ }^{\mathrm{a}}$

\begin{tabular}{lcrr}
\hline Land cover & $\begin{array}{c}1992-1984 \\
(\%)\end{array}$ & $\begin{array}{c}\text { 1999-1992 } \\
(\%)\end{array}$ & Overall change (1999-1984) \\
\hline Closed woodland & $-23 \cdot 88$ & $-9 \cdot 83$ & $-33 \cdot 71$ \\
Open woodland & $36 \cdot 35$ & $-13 \cdot 10$ & $23 \cdot 25$ \\
Grassland & $-14 \cdot 44$ & $8 \cdot 46$ & $-5 \cdot 98$ \\
Cultivated land & $1 \cdot 95$ & $14 \cdot 34$ & $16 \cdot 29$ \\
Settlement & $0 \cdot 02$ & $0 \cdot 12$ & $0 \cdot 14$ \\
Water & $0 \cdot 00$ & $0 \cdot 00$ & $0 \cdot 00$ \\
\hline
\end{tabular}

${ }^{\mathrm{a}}$ Total land area $=11176$ ha.

Table III. Land cover change matrix (\%)

\begin{tabular}{|c|c|c|c|c|c|c|}
\hline & \multicolumn{6}{|c|}{ From 1984} \\
\hline & $\begin{array}{c}\text { Closed } \\
\text { woodland }\end{array}$ & $\begin{array}{c}\text { Open } \\
\text { woodland }\end{array}$ & Grassland & $\begin{array}{c}\text { Cultivated } \\
\text { land }\end{array}$ & Settlement & Water \\
\hline \multicolumn{7}{|l|}{ To 1999} \\
\hline Closed woodland & $8 \cdot 71$ & 1.83 & $7 \cdot 03$ & 0.03 & 0.01 & $0 \cdot 00$ \\
\hline Open woodland & $20 \cdot 87$ & $7 \cdot 73$ & $11 \cdot 81$ & 0.09 & 0.04 & $0 \cdot 01$ \\
\hline Grassland & $8 \cdot 75$ & $6 \cdot 32$ & 9.93 & $0 \cdot 08$ & $0 \cdot 01$ & $0 \cdot 00$ \\
\hline Cultivated land & $12 \cdot 84$ & $1 \cdot 37$ & $2 \cdot 26$ & 0.03 & 0.01 & $0 \cdot 00$ \\
\hline Settlement & $0 \cdot 14$ & $0 \cdot 05$ & $0 \cdot 03$ & $0 \cdot 00$ & $0 \cdot 00$ & $0 \cdot 00$ \\
\hline Water & $0 \cdot 01$ & $0 \cdot 00$ & $0 \cdot 00$ & $0 \cdot 00$ & $0 \cdot 00$ & $0 \cdot 00$ \\
\hline
\end{tabular}


respectively. Cultivated land experienced an increase of about 2 per cent. The dominant land-cover change process was wood extraction for domestic uses, and charcoal production for commercial purposes by wood traders from Tamale.

There was a phenomenal increase of over 14 per cent in cultivated land in the second period (1992-1999). This suggests that demand for food by the growing population was an important driving force. Agricultural expansion is largely determined by a combination of total land availability, agricultural suitability of the soil and cropping/ fallow ratio. Since Wuripe is a newly colonized area with a low population density $\left(14\right.$ people $\left.\mathrm{km}^{-2}\right)$, the households have an unrestricted opportunity to increase the size of their cultivated land. Furthermore, land tenure is remarkably favourable to farming households, as allocation of land by the village chief is done according to household needs without prejudice to the principle of common ownership.

Only 26 per cent of the land did not change between 1984 and 1999 (sum of diagonal elements in Table III). A transition of about 21 per cent occurred from closed woodland in 1984 to open woodland in 1999, and of about 13 per cent of closed woodland in 1984 to cultivated land in 1999. More than 6 percent of open woodland was converted to grassland. Farming, charcoal burning and firewood collection being the activities associated with the changes. Yet transition to more vegetation also occurred: 2 per cent of open woodland in 1984 to closed woodland in 1999, and 7 percent and 12 percent of grassland in 1984 to closed woodland and open woodland in 1999 respectively. These processes are related to natural and secondary regrowth, and also reflect the still low population density at Wuripe. The analysis in Table IV shows that transition to less vegetation occurred more (36 per cent of land surface) than transition to more vegetation (21 per cent). Comparing Tables II and IV shows that transition to more vegetation is higher than conversion to agricultural land (16 percent). This indicates that farmers tend to create a stable bush fallow system maintaining a certain level of soil fertility.

\section{SOCIOECONOMIC SURVEY AND ANALYSIS}

A household survey was conducted at Wuripe between September and October 2001. From the original 42 farming households sampled at random, 35 (about 18 per cent) were chosen based on the availability of needed information for modelling. The survey focused on the demographic characteristics of migrant households, reasons for migrating to Wuripe, technology employed for farming, farm size and marketing of cereals. The questionnaire was designed to emphasize the factors associated with increase/decrease in plots cultivated by the household over the farming seasons spent at Wuripe. Linear multiple regression was used to identify the variables driving land-use change at the household level. Since all households did not migrate to Wuripe at the same time, dependent and independent variables for each household were developed to reflect the number of years spent at Wuripe. This eliminates possible bias in the analysis. A summary of the variables in the regression model after eliminating independent variables that exhibited high multicollinearity (that is, tolerance below $0 \cdot 2$ ) is presented in Table V.

\section{Migration Trends}

Figure 4 is a representation of the trend in settlement at Wuripe from 1989 to 2001 . The graph indicates that less than 20 per cent of the households migrated before 1992, whereas the remaining 80 per cent migrated into Wuripe from 1992 onwards. Thus, most of the population movements occurred in the post-structural adjustment era. This may be due to high macroeconomic instability resulting in higher inflation in the 1990s. A higher per cent of migrants in the post-structural adjustment era further confirms that most of the land-cover change processes between 1984 and 1992 were due to the activities of wood traders.

\section{Reasons for Out-migration}

The sampled households cited six reasons for migrating to Wuripe (Table VI). It is apparent that soil quality deterioration at the source of migration and access to land were the major migration push factors. Smith (1991) has already indicated that access to land in rural areas could reverse rural-urban migration. The relatively more secure land tenure (an institutional factor) at Wuripe is obviously a pull factor. Institutions apparently are mediators of 


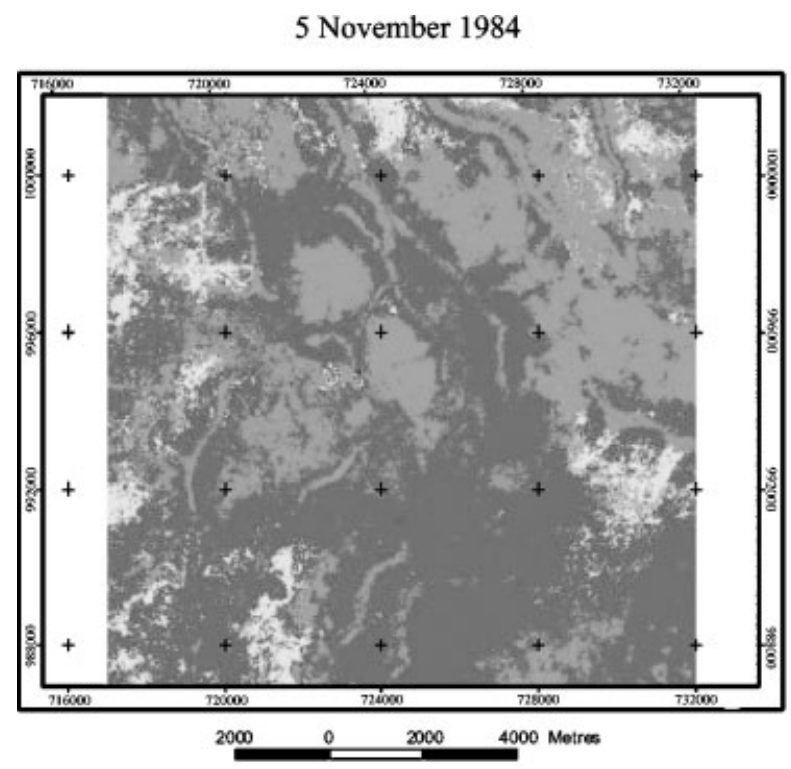

21 December 1992

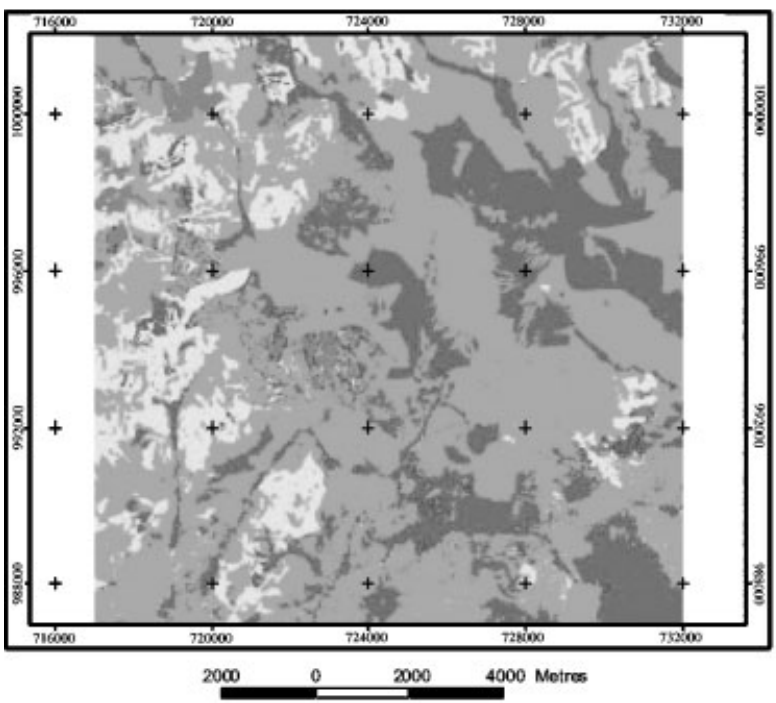

$\mathbf{N}$

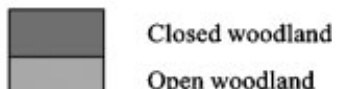

Open woodland

Grassland

Cultivated land

Settlement

Water

Figure 2. Land-cover maps for Wuripe. 
7 November 1999

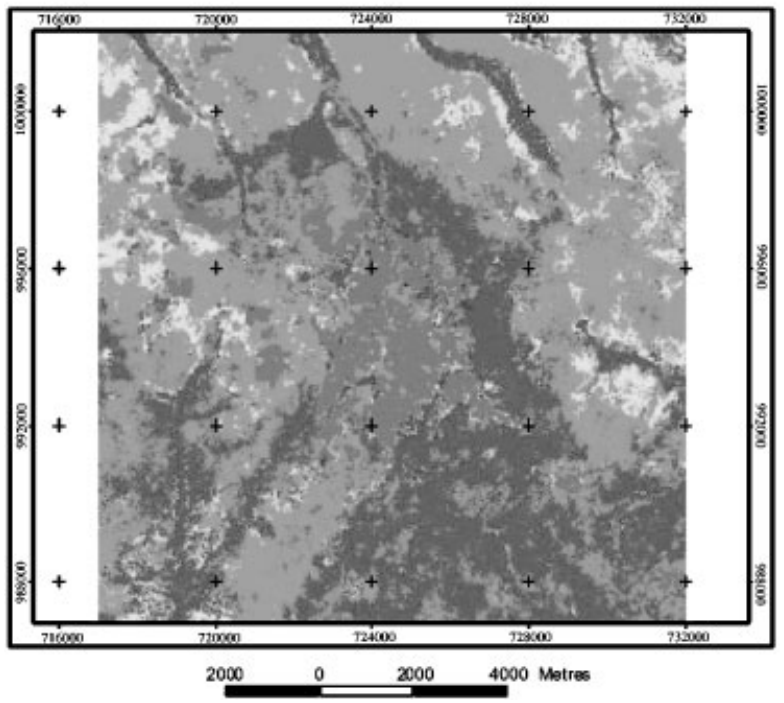

Figure 2. Continued

access to livelihood resources. Institutions determine directly, or indirectly, the outcomes of livelihood strategy embarked upon by the household (Scoones, 1998).

\section{Factors Affecting Land-use Change}

Tables V and VII indicates that, on average, farm size increased yearly by about $0 \cdot 3$ ha. A typical household head is in the middle-age group. Average increase in household size was 3 persons, while the average increase in farm labour was about 2 persons. The average increase in child-dependency ratio was about $0 \cdot 5$, suggesting an appreciable increase in the proportion of dependants. The average proportion of maize marketed (37 per cent) was less than that of rice (46 per cent). On average about one-third of the period spent at Wuripe was allowed for fallow.

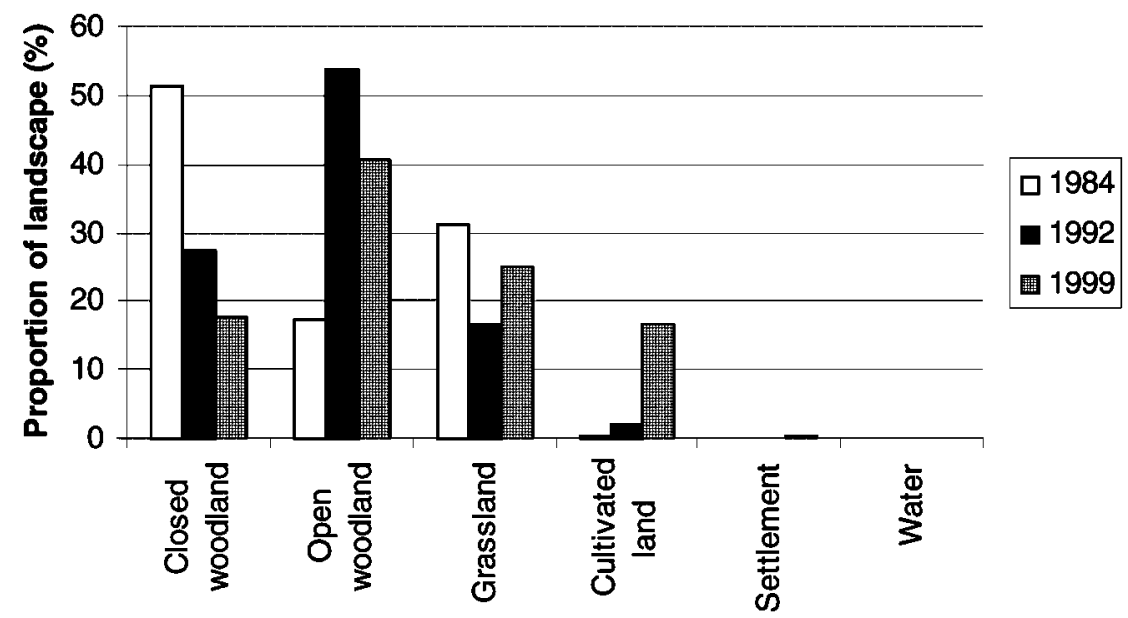

Figure 3. Land-cover proportions. 
Table IV. Changes in vegetation types between 1984 and 1999

\begin{tabular}{lrlr}
\hline Transition to less vegetation $(\%)$ & & Transition to more vegetation $(\%)$ \\
\hline Closed woodland to open woodland & $20 \cdot 87$ & Open woodland to closed woodland & $1 \cdot 83$ \\
Closed woodland to grassland & $8 \cdot 75$ & Grassland to closed woodland & $7 \cdot 03$ \\
Open woodland to grassland & $6 \cdot 32$ & Grassland to open woodland & $11 \cdot 81$ \\
Total & $35 \cdot 94$ & Total & $20 \cdot 67$ \\
\hline
\end{tabular}

The combined effects of the independent variables on the multiple regression model are discussed as follows:

Demographic variables. Multiple regression analysis shows that there was a strong and positive relationship between land-use change (farm size) and change in household size $(p<0 \cdot 01)$. This confirms that land-use change is driven by increase in demand for food. A negative relationship between age of household head (main decision maker) and change in land use shows that most of the increases in land-use change were associated with households with younger household heads. There was a negative and significant relationship between land-use change and change in age structure of household $(p=0.05)$. This implies that increases in land-use change were associated with households with a smaller proportion of children.

Technology. According to Mertens et al. (2000), technological evolution can be evaluated by changes in fallow period and change in inputs (labour force, fertilizer, machinery, etc.) employed by the household. Fertilizer use and

Table V. Variables in the multiple-regression model and their descriptive statistics

\begin{tabular}{|c|c|c|c|c|c|}
\hline Variables & Definition & Minimum & Mean & Maximum & Std. Dev. \\
\hline \multicolumn{6}{|c|}{ Dependent variable } \\
\hline Farm size & $\begin{array}{l}\text { Change in total land area cultivated by } \\
\text { household between year of inception at } \\
\text { Wuripe and the year } 2001 \text { divided by } \\
\text { length of time spent at Wuripe (ha } \mathrm{yr}^{-1} \text { ) }\end{array}$ & $-0 \cdot 33$ & $0 \cdot 25$ & $1 \cdot 15$ & $0 \cdot 34$ \\
\hline \multicolumn{6}{|c|}{ Independent variables } \\
\hline Distance & $\begin{array}{l}\text { Maximum distance travelled by } \\
\text { household to farm plots }(\mathrm{km})\end{array}$ & $0 \cdot 50$ & $2 \cdot 40$ & $6 \cdot 00$ & $1 \cdot 38$ \\
\hline Age & Age of household head (years) & $27 \cdot 00$ & $45 \cdot 03$ & $70 \cdot 00$ & $12 \cdot 07$ \\
\hline $\begin{array}{l}\text { Child dependency } \\
\text { ratio }\end{array}$ & $\begin{array}{l}\text { The difference between the ratio } \\
\text { no. of people } \leq 15 \text { years }\end{array}$ & $-1 \cdot 50$ & $0 \cdot 45$ & $2 \cdot 33$ & $0 \cdot 72$ \\
\hline & $\begin{array}{l}\text { No. of people }>15 \text { years and actively engaged in farming } \\
\text { at inception at Wuripe and } 2001\end{array}$ & & & & \\
\hline Labour & $\begin{array}{l}\text { Change in farm labour between } \\
\text { inception at Wuripe and } 2001 \text { (persons) }\end{array}$ & $0 \cdot 00$ & 1.69 & $7 \cdot 00$ & $1 \cdot 51$ \\
\hline Maize & $\begin{array}{l}\text { Mean proportion of harvested maize that } \\
\text { is sold over the period (years) spent at } \\
\text { Wuripe }(\%)\end{array}$ & 10 & 37 & 60 & 12 \\
\hline Rice & $\begin{array}{l}\text { Mean proportion of harvested rice that } \\
\text { is sold over the period (years) spent at } \\
\text { Wuripe }(\%)\end{array}$ & 10 & 46 & 80 & 18 \\
\hline Fallow & $\begin{array}{l}\text { Number of years allowed for fallow divided } \\
\text { by length of time (years) spent at Wuripe }\end{array}$ & $0 \cdot 00$ & $0 \cdot 33$ & $0 \cdot 75$ & $0 \cdot 25$ \\
\hline Fertilizer & $\begin{array}{l}\text { Number of years household has used fertilizer } \\
\text { divided by length of time (years) spent at Wuripe }\end{array}$ & $0 \cdot 00$ & $0 \cdot 21$ & $1 \cdot 00$ & $0 \cdot 37$ \\
\hline Tractor & $\begin{array}{l}\text { Number of years household has used tractor } \\
\text { divided by length of time (years) spent at Wuripe }\end{array}$ & $0 \cdot 00$ & $0 \cdot 36$ & $1 \cdot 00$ & $0 \cdot 42$ \\
\hline Household size & $\begin{array}{l}\text { Change in household size between inception at } \\
\text { Wuripe and } 2001 \text { (persons) }\end{array}$ & 1.00 & $3 \cdot 06$ & $12 \cdot 00$ & $2 \cdot 25$ \\
\hline
\end{tabular}




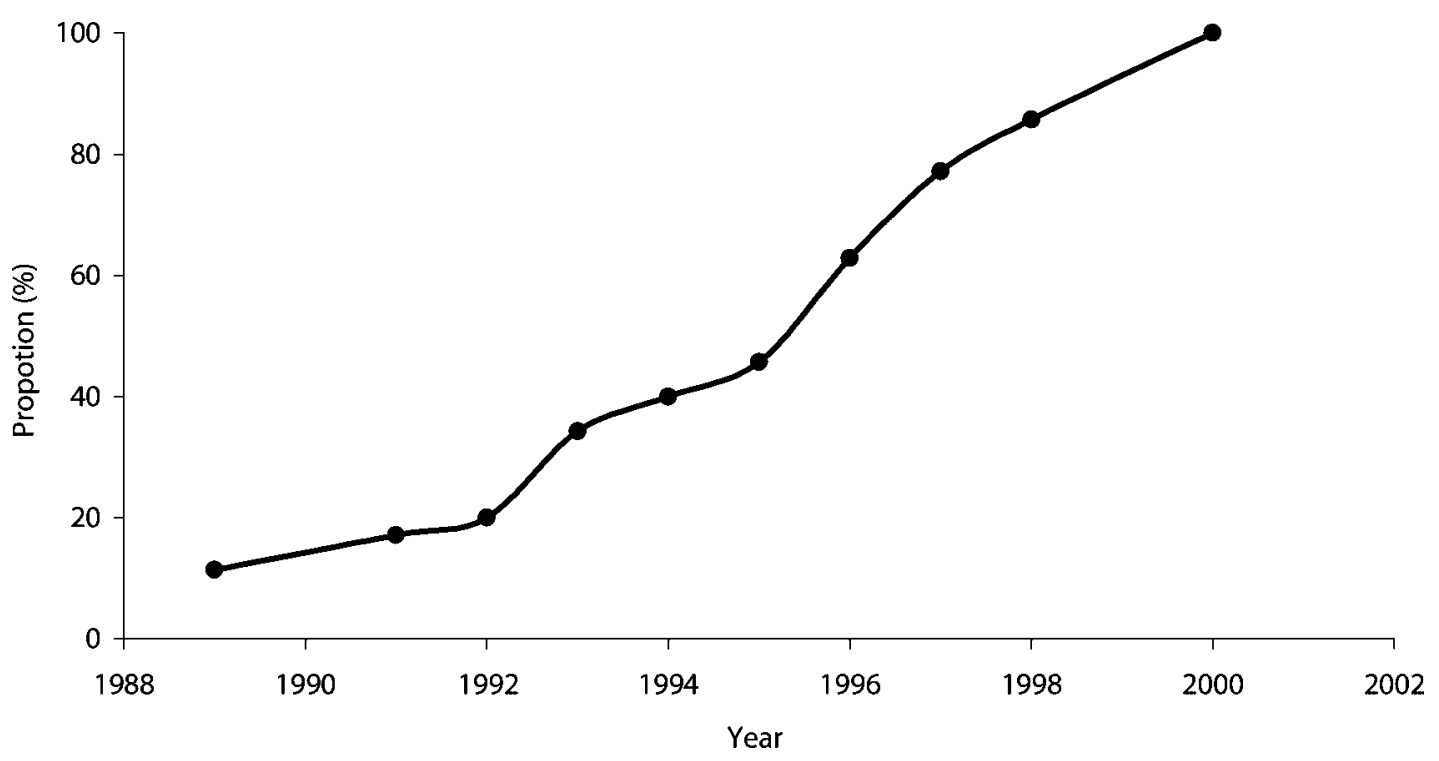

Figure 4. Cumulative distribution of household migration to Wuripe.

fallow were inversely related to land-use change. This suggests an increase in land-use intensity. A strong relationship between land-use change and fertilizer use was observed. An increase in fertilizer use tends to decrease the size of hectares cultivated by a household, other factors remaining constant. Change in fallow length appears to be a weak predictor of land-use change at the household level.

As fallow length generally tends to decrease rather than increase due to population pressure, the inverse relationship also confirms the phenomenon of agricultural intensification at the household level. Change in labour was not significantly related to land-use change $(p>0.05)$, whereas there was a strong and positive relationship between land-use change and tractor use $(p<0.01)$. This suggests a tendency to substitute tractors for farm labourers in farming activities.

Market variables. There was a positive, but non-significant, relationship between distance and land-use change. Households tend to create new farmlands at more distant places. Evolution of the marketing of cereals measured as the average proportions of maize and rice sold show negative and positive relationships with land-use change respectively. The evolution of the marketing of rice was also significantly related to land-use change. In order to meet increasing local demand, there has been an increase in the land area devoted to rice production in Northern Ghana. Accessibility to market (Tamale) further encourages the sale of agricultural produce.

Table VI. Declared reasons for migrating to Wuripe ${ }^{a}$

\begin{tabular}{lc}
\hline Reason & Proportion $(\%)$ \\
\hline Declining soil fertility & 51 \\
Scarcity of land at source of migration & 37 \\
To increase output/make more income & 23 \\
Changed employment to farming & 17 \\
Irregular/unreliable rainfall & 6 \\
Ethnic conflict & 3 \\
\hline
\end{tabular}

${ }^{\text {a }}$ Values do not add up to 100 per cent because most households cited more than one cause of out-migration. 
Table VII. Land use change model for Wuripe ${ }^{\mathrm{a}}$

\begin{tabular}{lrr}
\hline & Standardized $\beta$ & Sig. Prob. \\
\hline Age & $-0 \cdot 14$ & $0 \cdot 13$ \\
Household size & $0 \cdot 38$ & $<0 \cdot 01$ \\
Child depedency ratio & $-0 \cdot 22$ & $0 \cdot 05$ \\
Labour & $-0 \cdot 08$ & $0 \cdot 41$ \\
Tractor & $0 \cdot 41$ & $<0 \cdot 01$ \\
Fallow & $-0 \cdot 05$ & $0 \cdot 56$ \\
Fertilizer & $-0 \cdot 40$ & $0 \cdot 01$ \\
Rice & $0 \cdot 54$ & $<0 \cdot 01$ \\
Maize & $-0 \cdot 07$ & 0.43 \\
Distance & $0 \cdot 11$ & $0 \cdot 26$ \\
$R^{2}$ & & $0 \cdot 84$ \\
Adjusted $R^{2}$ & & $0 \cdot 77$ \\
Sig. Prob. & & $<0 \cdot 01$ \\
\hline
\end{tabular}

${ }^{\mathrm{a}}$ Dependent variable: farm size.

\section{CONCLUSIONS AND POLICY IMPLICATIONS}

Macroeconomic transformations in Ghana have played a major role in migration patterns and land-use/land-cover change in Wuripe. The analysis of Landsat images revealed high rates of decrease in closed woodland in the structural adjustment period. However, only about 20 per cent of households migrated to Wuripe in the structural adjustment period, indicating that woodcutting for commercial purposes was the main cause of vegetation degradation during that period. Devaluation, and other instruments of structural adjustment, appeared to have had a strong ecological impact by increasing pressure on vegetation resources. Decline in closed woodland occurred in the post-adjustment era, but was not as high as the increase in cultivated land. Less favourable economic opportunities at sources of migration encouraged in-migration to Wuripe in the post-structural adjustment period. Resulting population increases led to expansion of cultivated areas to woodlands.

Land-use changes were a result of coexistent processes of extensification and intensification. The driving factors were household size, proportion of dependants, tractor use, fertilizer use, and the evolution of the marketing of rice. The increase in the use of fertilizer, despite fiscal policies that reduced fertilizer subsidies, could be interpreted in the light of farmers' responses to marketing opportunity for sales of local rice. Increase in tractor use on the other hand may be explained by government measures to mitigate the effects of adjustments. For instance, Jebuni and Seini (1992) observed that, while there was a tremendous increase in the nominal cost of tractor hire during the adjustment era, in real terms farmers paid 70 per cent less for ploughing in 1990 than they did in 1980. The increased flow of spare parts was cited as a possible explanation for this.

Analyses of local pattern of land-use and land-cover change as carried out in this study could provide relevant information for policy makers who are responsible for environmental protection. While the provision of a basic infrastructure (e.g. potable water, health facility, schools, etc.) to facilitate the permanent settlement of people is required at Wuripe, there is also the need for an environmental education and awareness programme on the consequences of woodcutting for firewood and charcoal. The development of alternative sources of energy could also minimize the overall impact of woodcutting.

Decline in closed woodland as a result of illegal woodcutting underscores the need for coercive environmental protection policies to relieve human pressure on vegetation resources. Phenomenal agricultural expansion at the expense of woodland also calls for agricultural intensification-related policy initiatives to discourage expansion of cultivation on fragile lands. Such intensification strategies should address sustainable soil management and farming techniques. Given the fact that aridity generally decreases the ease with which sustainable farming techniques can be developed (Øygard et al., 1999) and integrated nutrient management implemented (Donovan and Casey, 1998; Vanlauwe et al., 2002), an approach that combines organic and mineral methods of soil 
fertilization with physical and biological measures for soil and water conservation could be a promising soilmanagement technique. The research required to develop this intensification programme needs to be site-specific and should involve local farmers in its implementation.

\section{ACKNOWLEDGEMENT}

This research was carried out under the GLOWA-VOLTA project funded by the German Federal Ministry for Education and Research (Grant Number 07GWK01), with additional support from the Ministry for Schools, Science and Research of Northrhine Westphalia. The German Academic Exchange Services (DAAD) are also thanked for a scholarship award. The comments of Thomas Berger, Ulrike Grote and anonymous referees on an earlier draft of this manuscript are also sincerely acknowledged.

\section{REFERENCES}

Abdulai A, Hazell P. 1995. The role of Agriculture in sustainable Development in Africa. Journal of Sustainable Agriculture 7: 101-119.

Abdulai A, Huffman W. 2000. Structural adjustment and economic efficiency of rice farmers in northern Ghana. Iowa Agriculture and Home Economic Experiment Station, Journal Paper J-18549, Iowa.

Abudulai S. 1996. Perceptions of land rights, rural-urban land-use dynamics and policy development. In Managing Land Tenure and Resource Access in West Africa. Proceedings of a regional workshop held at Goree, Senegal, November 18-22, 1996. pp. 107-127.

Ahmed II, Lipton M. 1997. Impact of structural adjustment on sustainable rural livelihoods: a review of the literature. IDS Working Paper 62, University of Sussex, UK.

Andreini M, van de Giesen N, van Edig A, Fosu M, Andah W. 2000. Volta basin water balance. ZEF Discussion Papers on Development Policy, No. 21. Center for Development Research, Bonn, Germany.

Asante F, Berger T, Engel S, Iskandarani M. 2002. Water security in the Ghanaian Volta basin: patterns, determinants and consequences. Quarterly Journal of International Agriculture 41(1/2): 145-167.

Donovan G, Casey F. 1998. Soil fertility management in sub-Saharan Africa. World Bank Technical Paper, No. 408. Washington, DC, World Bank.

Hall FG, Strebel DE, Nickeson JE, Goetz SJ. 1991. Radiometric rectification: toward a common radiometric response among multidate, multisensor images. Remote Sensing of Environment 35: 11-27.

Horton S, Kanbur R, Mazumadar D (eds). 1994. Labour Markets in an Era of Adjustment, Vol. I and II. Economic Development Institute of the World Bank, Washington, DC.

Jebuni C, Seini W. 1992. Agricultural input policies under structural adjustment: Their distributional implications. Cornell Food and Nutrition Policy Program Working Paper, No. 31. Ithaca, NY, USA, Cornell University.

Mertens B, Sunderlin WD, Ndoye O, Lambin EF. 2000. Impact of macroeconomic change on deforestation in South Cameroon: integration of household survey and remotely sensed data. World Development 28(6): 983-999.

Overseas Development Institute. 1999. Rethinking natural resources degradation in semi-arid sub-Saharan Africa: The case of semi-arid Ghana. ODI Rural Policy and Environment Group, UK.

Øygard R, Vedeld T, Aune J. 1999. Good Practices in Drylands Management. Noragric Agricultural University of Norway, As, Norway.

Pearce R. 1992. 'Ghana' In Structural Adjustment and the African Farmer, Duncan A, Howel J (eds). Overseas Development Institute: London. Scoones I. 1998. Sustainable rural livelihoods: A framework for analysis. IDS Working Paper 72.

Smith L. 1991. Agricultural labor markets and structural adjustment in sub-saharan Africa. Economic and Social Development Paper No. 99, FAO, Rome.

Tshikata YM. 1999. Aid and reform in Ghana. http://www.worldbank.org/research/aid/africa/ghana. pdf cited on 26 May 2002.

Vanlauwe B, Diels J, Saginga N, Merckx R (eds). 2002. Integrated plant nutrient management in sub-Saharan Africa. http://www.cabipublishing.org/Bookshop/Readingroom/o851995764.asp. Cited on 9 July 2002. 